\section{Application of Paper Chromatography to the Study of the Transaminase System}

TRansamrnase reactions are known to occur in practically all animal tissues, especially in heart muscle, brain, kidney, liver and testes. Reactions of this type were first suggested by Needham ${ }^{1}$, who noted that when glutamic acid was added to minced pigeon-breast muscle it disappeared without a parallel formation of ammonia. Four or five different transaminase systems have so far been thoroughly investigated by various workers ${ }^{2}$; but the methods employed for the study of these reactions have required manometric equipment ${ }^{3}$ and intensive analytical procedures ${ }^{4}$. 'T'he present communication deals with the application of paper chromatography technique to the separation of $2: 4$ dinitrophenylhydrazones of the keto-acids in the reaction mixture, since it has proved in our hands a satisfactory tool for the study of transaminase reactions. The reaction studied was :

L-Aspartate $+\alpha$-Ketoglutarate $=$

Oxalacetate + L-Glutamate.

This reaction was allowed to proceed for different intervals in a series of small centrifuge tubes in the presence of liver enzyme, coenzyme from muscle (boiled muscle extract) and excess aspartate. $\alpha$-Ketoglutarate was added in known amounts. Oxalacetic acid formed by the enzyme action was converted chemically to pyruvic acid by means of aniline citrate as described by Tonhazy, White and Umbreit ${ }^{5}$. Unreacted $\alpha$-ketoglutarate and the resulting pyruvate were converted into their $2: 4$ dinitrophenylhydrazones. For further separation of these two compounds, partition chromatography on filter paper, as described by Cavallini, Frontali and Toschi, was used. A typical experiment is described below.

A normal adult rat from the stock colony was killed by stunning; liver and muscle were dissected out and a 2 per cent liver homogenate $(w / v)$ was prepared immediately in ice-cold phosphate buffer of $p \mathrm{H} \mathrm{7 \cdot 4}$. Boiled muscle extract $(1 \mathrm{ml}$. equivalent to $100 \mathrm{mgm}$. of fresh muscle) was prepared in physiological saline solution. The following solutions were added to each of the six centrifuge (5-ml. capacity) tubes: $0.5 \mathrm{ml}$. buffered $M$ aspartate, $0.5 \mathrm{ml}$. phosphate buffer $p H \mathbf{H} 7 \cdot 4,0 \cdot 2 \mathrm{ml}$. of boiled muscle extract and $0.1 \mathrm{ml}$. of $\alpha$-ketoglutarate solution $(400 \mu \mathrm{gm} . / \mathrm{ml}$.). The reaction mixture was brought to $37^{\circ} \mathrm{C}$. in a water-bath; $0.2 \mathrm{ml}$. of liver homogenate was then added to each tube with mixing, and the reaction allowed to proceed at $37^{\circ} \mathrm{C}$. At definite intervals, the contents of one tube were treated with $0.2 \mathrm{ml}$. of 100 per cent $(\mathrm{w} / \mathrm{v})$ solution of trichloroacetic acid in order to precipitate proteins. Oxalacetate formed in the reaction mixture was converted to pyruvate by adding 0.2 c.c. of aniline citrate to each tube. Thus, the keto-acids in the tube consisted of excess unchanged $\alpha$-ketoglutaric acid and pyruvic acid derived from the oxalacetic acid formed during the transaminase reaction.

The two keto acids were converted into their respective dinitrophenylhydrazones by the addition of $1 \mathrm{ml}$. of 0.2 per cent $2: 4$ dinitrophenylhydrazine in $2 N$ hydrochloric acid. The precipitated proteins were removed by centrifugation, and the excess of hydrazine and hydrazones formed were quantitatively extracted with ethyl acetate by the method of Bueding and Wortis?. The ethyl acetate portions were then extracted three times with $2 \mathrm{ml}$. of 10 per cent sodium carbonate solution. The combined carbonate extracts were freed from dinitrophenylhydrazine by a further extraction with $2 \mathrm{ml}$. ethyl acetate, and were acidified with concentrated hydrochloric acid to obtain free hydrazones of pyruvic and $\alpha$-ketoglutaric acids. They were then transferred into $2 \mathrm{ml}$. toluene by shaking. $0.5 \mathrm{ml}$. of this material was disposed on a filter paper strip (Whatman No. 4 filter paper) and an ascending chromatogram was run for $24 \mathrm{hr}$. at $25^{\circ} \mathrm{C}$. using butanol-ethanol-water (50:10:40 v/v respectively) as solvent. The strip was dried and the portions of filter paper around the spots, previously identified by their $R_{F}$ values $\left(R_{F}\right.$ values of dinitrophenylhydrazones of pyruvic and $\alpha$-ketoglutaric acids were 0.55 and 0.37 respectively), were cut into small bits and the yellow-coloured hydrazones were extracted thrice with $2 \mathrm{ml}$. of 10 per cent sodium carbonate. The red colour developed after addition of $4 \mathrm{ml}$. of $2 \mathrm{~N}$ sodium hydroxide was compared in a photoelectric colorimeter with filter $530 \mathrm{~m} \mu$ in position. Standard curves obtained with pure samples of the dinitrophenylhydrazones of the two acids were used for reference.

The average results obtained in four experiments with normal rat liver preparations are summarized in the accompanying table.

\begin{tabular}{|c|c|c|c|c|c|c|}
\hline $\begin{array}{c}1 \\
\text { Time } \\
(\min .)\end{array}$ & $\begin{array}{c}2 \\
\alpha \text {-Keto- } \\
\text { glutar- } \\
\text { ate } \\
\text { added } \\
(\mu \text { gm. })\end{array}$ & $\begin{array}{c}3 \\
\alpha \text {-Keto- } \\
\text { glutar- } \\
\text { ate un- } \\
\text { reacted } \\
\text { recov- } \\
\text { ered } \\
\text { ( } \mu \text { gm.) }\end{array}$ & $\begin{array}{c}1 \\
\text { Pyruv- } \\
\text { ate re- } \\
\text { covered } \\
(\mu \mathrm{gm} .)\end{array}$ & $\begin{array}{l}5 \\
\alpha \text {-Ketoglut- } \\
\text { arate equi- } \\
\text { valent of } \\
\text { pyruvate } \\
\text { formed } \\
(\mu \mathrm{gm} .)\end{array}$ & $\begin{array}{c}6 \\
(3) \\
+ \\
(5) \\
(\mu \mathrm{gm} .)\end{array}$ & $\begin{array}{c}7 \\
\text { Recovery } \\
\text { per cent } \\
\frac{(6)}{(2)} \times 100\end{array}$ \\
\hline $\begin{array}{r}4 \\
8 \\
16 \\
20 \\
24\end{array}$ & $\begin{array}{l}40 \\
40 \\
40 \\
40 \\
40\end{array}$ & $\begin{array}{r}32 \cdot 4 \\
26 \cdot 3 \\
17 \cdot 6 \\
9 \cdot 6 \\
4 \cdot 9\end{array}$ & $\begin{array}{r}6 \cdot 1 \\
7 \cdot 4 \\
12 \cdot 9 \\
19 \cdot 0 \\
18.8\end{array}$ & $\begin{array}{l}10 \cdot 2 \\
12 \cdot 3 \\
21 \cdot 4 \\
31 \cdot 5 \\
31 \cdot 2\end{array}$ & $\begin{array}{l}42 \cdot 6 \\
38 \cdot 6 \\
39 \cdot 0 \\
41 \cdot 1 \\
36 \cdot 1\end{array}$ & $\begin{array}{r}106 \\
97 \\
98 \\
103 \\
90\end{array}$ \\
\hline
\end{tabular}

It can be seen from these results that, under the conditions specified here, the velocity of the transaminase reaction in question could be conveniently followed. In $24 \mathrm{~min}$., 88 per cent of $\alpha$-ketoglutaric acid present in the reaction mixture was converted to oxalacetic acid. Also, good recoveries of pyruvic and $\alpha$-ketoglutaric acids were obtained by adopting this procedure, and the proportionality between different quantities was very close. The technique, though somewhat time-consuming, is simple and convenient, and will be found useful in laboratories where the expensive Warburg manometric outfit is not available.

\section{P. G. Tulpule}

V. N. PatwardhaN

Nutrition Research Laboratories,

Indian Council of Medical Research,

Coonoor.

Nov. I.

${ }^{1}$ Needham, D. M., Biochem. J., 24, 208 (1930),

2 Cohen, P. P., J. Biol. Chem., 136, 565 (1940). Cohen, P. P., and ohen, P. P., J. Biol. Chem., 136, 565 (1940). Cohen, P. P. and "Aekhuis, G. I.., J. Biol, Chem., 140,

${ }^{3}$ Ames, S. R., and Elvehjem, C. A., J. Biol. Chem., 166, 81 (1946), Ames, S. R., Sarma, P. S., and Elvehjem, C. A., J. Biol. Chem., $16 \%, 135$ (194' 7 ).

4 Cohen, P. P., Biochem. J., 33, 1478 (1939).

${ }^{5}$ Tonhazy, N. E., White, N. G., and Umbreit, W. W., Arch. Biochem., $28,36(1950)$.

5 C'avallini, D. Frontali, $\mathrm{Y}$, and Toschi, G., Nature, 163, 568 (1949).

? Bueding, E., and Wortis, H., J. Biol. Chem., 133, 585 (1940). 